\title{
The Potential of Lipolytic Filamentous Fungi Isolated from Landfill Soil as Poly- $\beta$ - Hydroxybutirate (PHB) Bioplastic Degrader
}

\author{
Nur Arfa Yanti ${ }^{1 *}$, Endang Sriwahyuni ${ }^{1}$, Nur Rayani La Omi ${ }^{1}$, Nurhayani H. Muhiddin ${ }^{2}$, Sitti \\ Wirdhana Ahmad ${ }^{1}$ \\ ${ }^{1}$ Department of Biology, Faculty of Mathematic and Natural Science, Halu Oleo University \\ Indonesia. 93232 \\ ${ }^{22}$ Faculty of Mathematics and Natural Science, Makassar State University, Makassar, \\ South Sulawesi, Indonesia \\ Corresponding author : nur.yanti@uho.ac.id
}

\begin{abstract}
The present study was investigated the potential of lipolytic fungi (molds) isolated from landfill soil in degrading Poly- $\beta$-hydroxybutyrate (PHB). Screening of PHB-degrading lipolytic molds was done in two stages, such as screening of lipolytic molds which was identified by the formation of orange fluorescent halos around the colony on rhodamine B agar medium and the degradation PHB ability test was identified by the formation of clear zone around colony on PHB emulsion medium. Characterization of isolates was done based on phenotypic characters and the identification was done by numerical-phenetic analysis. Three lipolytic mold isolates that have ability in degrading PHB bioplastic i.e isolate $\mathrm{KC} 1$, KE1 and KE6. These molds have asexual spore form conidia, foot cell, septate hyphae, unbranched conidiophore, and spore mass located at the apex of phialid. The identification results showed that isolate $\mathrm{KC} 1$ is identic to Aspergillus terreus, $\mathrm{KE} 1$ is identic to Aspergillus niger and KE6 is identic to Aspergillus fumigatus.
\end{abstract}

Keywords: lipolytic mold, landfill soil, degradation, $P H B$

\section{Introduction}

Generally, the commercial plastics are made of undegradable materials such as crude oils. They are difficult to be degrade, consequently they will be accumulated continuously over the time. This condition will give negative impact as pollutions in the environment. One of the solutions to anticipate it is the utilization of biodegradable plastic or bioplastic which is eco-friendly, such as poly- $\beta$-hydroxybutyrate (PHB) (Bharti and Swetha, 2016). PHB as a member of poly- $\beta$-hydroxyalkanoate (PHA) is widely produced at industrial scale.

PHB bioplastic has similar character with the polypropilene synthetic plastic, but PHB bioplastic can be produced using renewable resourches which are easier to be degrade in the environment. In additon, PHB is also biocompatible with alive tissues, so it can be applied in biomedical sector (Rathbone et al., 2009). Some studies has been reported that PHB is made of natural substrates by the action of microorganisms (Ramadas et al., 2009; Full et al., 2006; Lafferty et al., 1988). Yanti et al. $(2013 ; 2016)$ has been proposed the utilization of local sago starch from Southeast Sulawesi, Indonesia to produce PHB by bacteria, but its biodegradability is not been known.

PHB bioplastic can be degraded enzimatically by lipases becauce its monomer contains of ester bond. Lipases can catalyze the hydrolysis of this ester bond (Leja and Lewandowicz, 2010). However, the lipases enzyme are very expensive and this becomes an obstacle if they are used. Therefore, an alternative way is needed to solve this, such as exploring 
microorganisms with the capability to synthesis lipases.

Microorganism which is preferred as a great lipase-producing is molds (Falony et al., 2006; Thakur, 2012). There were many studies about the exploration of lipolytic molds, but their potential as PHB-degrading molds is still not well known. One of the potential source to find lipolytic molds is in landfill soil because this place is accumulated by the mixture of many wastes containing oil. The present study was conducted to isolate lipolytic molds from landfill soil, to test the potential of these isolates in degrading PHB and to identify them.

\section{Materials and Methods}

\section{Soil sampling}

Soil sample was obtained from Puuwatu landfill area, Kendari, Southeast Sulawesi, Indonesia. Sampling was collected from 5 zones (A, B, C, D and E) with 3 sampling points each area at a depth $\pm 20 \mathrm{~cm}$ from the ground surface. Zones A, B, C and D are former waste disposal areas and have changed functions while zone $\mathrm{E}$ is an active waste disposal area. The soil samples were collected in sterile plastics. Soil sample from 3 sampling points of each zone were composited before they were used.

2. Isolation of lipolytic molds

Potato Dextrose Agar (PDA) (Merck) medium was used in this isolation step. Ten grams of soil sample was suspended in $90 \mathrm{ml}$ of sterile distilled water and was shaken for 15 minutes. Serial dilution were made until $10^{-5}$. Then, $100 \mu$ dillutions were spread on medium and were incubated at $30^{\circ} \mathrm{C}$ for $1-2$ weeks. Mold colonies grown were purified on PDA plates and were incubated at $30^{\circ} \mathrm{C}$ for 7 days. Single colony was inoculated on PDA slants and stored at $4^{\circ} \mathrm{C}$.

3. Screening of lipolytic molds

Screening lipolytic molds was done qualitatively by growing each isolate on rhodamine-B agar medium and was incubated at $37^{\circ} \mathrm{C}$ for 7 days (Panuthai et al., 2012). Lipolytic activity was detected by irradiating plates with UV light at $365 \mathrm{~nm}$ (Murray, 2010).

4. Biodegradation test of PHB biofilm

PHB biofilm was obtained from previous study (Yanti et al., 2016). Isolates which have maximal lipolytic activity were grown on plastic emulsion agar medium to determine their biodegradation potential (Nathania and Kuswytasari, 2013). Isolates were incubated on medium using point technique and were incubated $30^{\circ} \mathrm{C}$ for 2 days. Biodegradation activity was determined by the the formation of clear zone around colony. The ratio of clear zone formed was calculated using the equation bellow (Nishida and Tokiwa, 1993).

$$
\text { Ratio of clear zone }(\mathrm{mm})=\frac{\text { diameter of clear zone }(\mathrm{mm})}{\text { diameter of mold colony }(\mathrm{mm})}
$$

5. Morphology characterization of PHB-degrading lipolytic mold

The morphology characterization was carried out macroscopically and microscopically. Macroscopic characteristics observed were the colour of obverse and reverse colony, topography, texture, rate of growth, exudate drops, radial line and diameter of colony. Microscopic characteristics observed were asexual spores, foot cell, septate or aseptate hyphae, conidia, vesicles type and conidiophore characteristics. Microscopic observation 
was used slide culture method (Sanjaya, 2010; Cappucino and Sharman, 1987). Obtained data were then compared with the descriptions of fungi species in the Training course for the identification of Aspergillus, Penicillium and Talaromyces (Samson, 2017).

6. Identification of PHB-degrading lipolytic mold

The identification was done by numerical-fenetic method. The mold isolates and reference species characteristics were analyzed using MVSP (Multi Variate Statistical Package) ver.3.1. The diversity of mold fenotipic characteristics were determined by Simple Matching Coefficient (SSM) value and the classification were based on UPGMA (Unweighted Pair Goup Method with Arithmatic Averages) algoritm. The results were visualized as dendrogram. The dendrogram was used to know the similarity of PHBdegrading lipolytic mold with 4 reference mold species, such as Aspergillus terreus, Aspergillus niger, Aspergillus flavus dan Aspergillus fumigatus.

\section{Results}

a. Lipolytic Molds Isolated from Kendari Landfill soil

Twenty four isolates were obtained from Kendari landfill soil. Isolates were screened in rhodamine-B agar medium. Lipolytic activity was indicated as orange fluorescent around the colony by irradiating each isolate in UV light at $\lambda=365 \mathrm{~nm}$. The higher of the fluorescense intencity, the higher lipoytic activity (Murray, 2010). Sixteen among twenty four isolates were lipolytic molds (Table 1). The difference fluoresent intencity was shown in Figure 1. Three selected lypolytic molds with the highest lipolytic activity were KC1, KE1 and KE6. Hence these isolates were used in the next steps of the study.

Table 1. Lipolytic activity based on fluorescent intencity

\begin{tabular}{ccc}
\hline Sampling Zone & Isolate Code & Fluorescent \\
\hline A & KA1 & ++ \\
A & KA2 & - \\
A & KA3 & - \\
B & KB1 & ++ \\
B & KB2 & - \\
B & KB3 & ++ \\
B & KB4 & - \\
C & KC1 & +++ \\
C & KC2 & + \\
C & KC3 & ++ \\
C & KC4 & + \\
D & KD1 & + \\
D & KD2 & + \\
E & KE1 & +++ \\
E & KE2 & ++ \\
E & KE3 & - \\
E & KE4 & + \\
E & KE5 & - \\
E & KE6 & +++ \\
E & KE7 & + \\
E & KE8 & - \\
\hline
\end{tabular}




\begin{tabular}{ccc}
\hline $\mathrm{E}$ & KE9 & + \\
$\mathrm{E}$ & KE10 & ++ \\
$\mathrm{E}$ & KE11 & - \\
& Positive control (lipase) & +++ \\
\hline Note: $(-)=$ no fluorescent $(+)=$ low fluorescent, $(++)=$ medium fluorescent $(+++)=$ high fluorescent
\end{tabular}

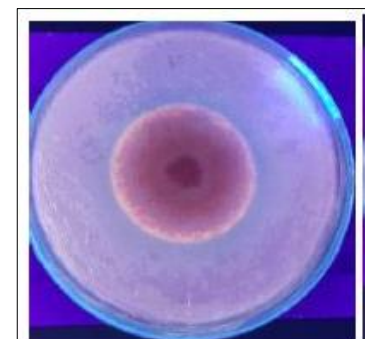

a

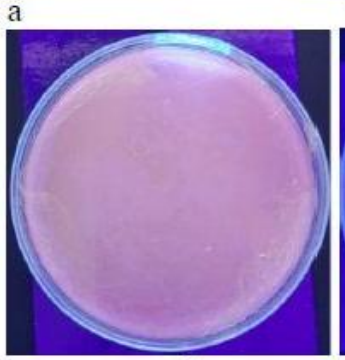

d

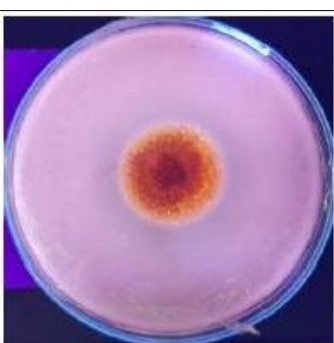

$\mathrm{b}$
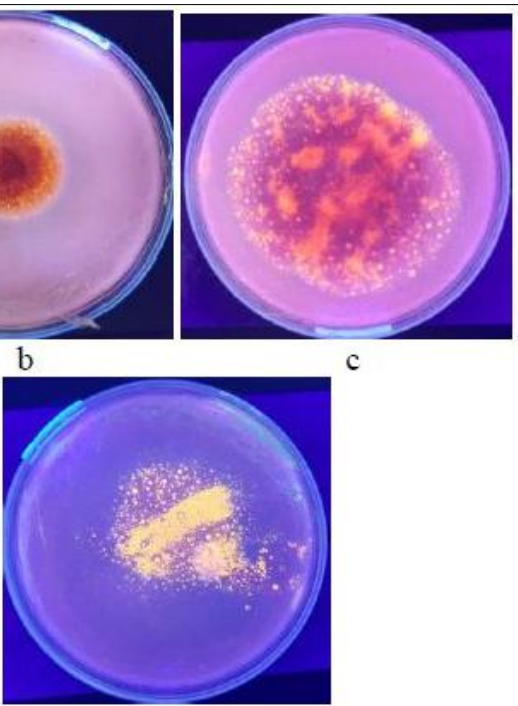

e

Figure 1. Fluorescent intencity of mold colonies on rhodamine-B agar media, a) low $(+)$, b) medium $(++), c)$ high $(+++)$, d) negative control, e) positive control

b. Degradation PHB by the selected lipolytic molds

Three selected molds with the highest lipolytic activity were tested in bioplastic emulsion medium to determine their ability in degrading poli- $\beta$-hidroksibutirat (PHB). Bioplastic film (PHB) used in this study was obtained from previous study by Yanti et al. (2009). Clear zone around the colony indicates that the isolate can degrade poly- $\beta$-hidroksibutirate (PHB) (Figure 2). The result of clear zone ratio measurement was shown in Table 2. According to the result obtained, all isolates had the ability to degrade PHB, but isolate KE6 was significantly different to the isolate $\mathrm{KC} 1$ and $\mathrm{KE6}$, while isolate $\mathrm{KC} 1$ and KE6 were not significantly different at $95 \%$ confidence level (Table 2). Three degrading PHB lipolytic molds were further characterized and indentified to determine their identities.

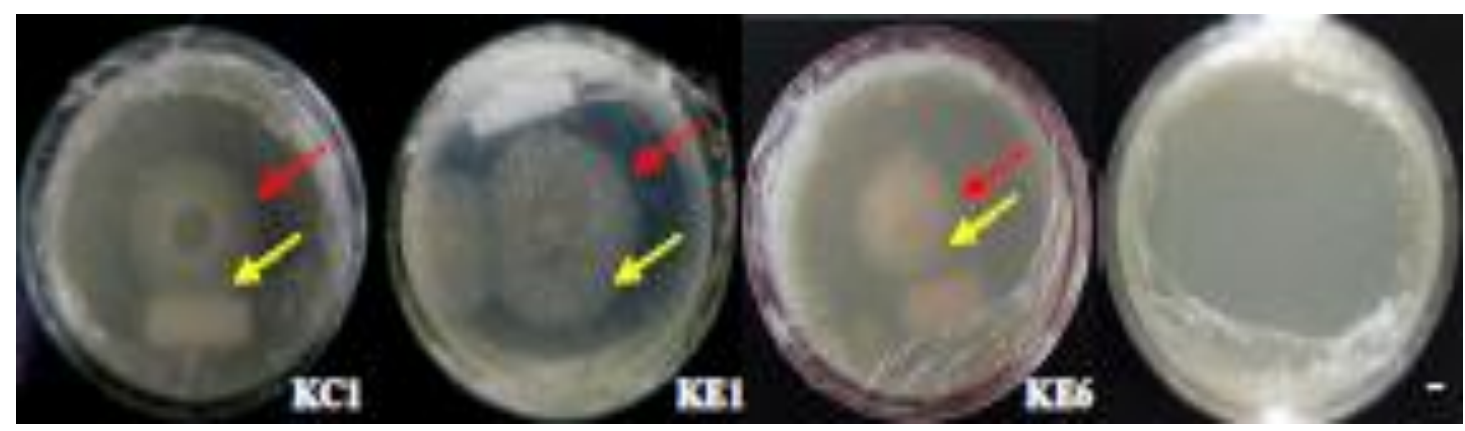

Note: $\rightarrow$ clear zone, $\rightarrow$ mold colony, $(-)=$ negative control

Figure 2. Degradation PHB of three lipolytic isolates 
Table 2. Degradation ability of three lipolytic molds after 2 days

\begin{tabular}{cccc}
\hline Isolate Code & $\begin{array}{c}\text { Diameter of clear zone } \\
(\mathrm{mm})\end{array}$ & $\begin{array}{c}\text { Diameter of colony } \\
(\mathrm{mm})\end{array}$ & Clear zone ratio \\
\hline KC1 & 15 & 12 & $1.25^{\mathrm{b}}$ \\
KE1 & 30.25 & 24.25 & $1.24^{\mathrm{b}}$ \\
KE6 & 21 & 18.97 & $1.10^{\mathrm{a}}$ \\
Negative control & - & - & - \\
\hline
\end{tabular}

Note: Unequal letter is significantly different according to Duncan test at $95 \%$ confidence level $(\mathrm{P}>0,05)$

c. Morphology Characteristics

Three selected isolates were observed based on macroscopic and microscopic characters. Macroscopically, these colony isolates were observed in PDA medium after 7 days. The macroscopic characteristics of the colony were shown in Table 3 and Figure 3. Microscopic characteristics of each isolate were shown in Table 4 and Figure 4.

Table 3. Macroscopic characteristics of three selected isolates

\begin{tabular}{lccc}
\hline \multirow{2}{*}{ Characteristics } & \multicolumn{3}{c}{ Isolate Code } \\
\cline { 2 - 4 } & KC1 & KE1 & KE6 \\
\hline Colony surface & Dark yellow & Black & Dark blue \\
Colony reverse & Yellow & Cream & Cream \\
Exudate & Absent & Absent & Present \\
Growth rate & Fast & Fast & Fast \\
Zonation & Present & Present & Absent \\
Texture & Powdery & Powdery & Powdery \\
Sporulation & Present & Present & Present \\
Diameter $(\mathrm{mm})$ & 46.75 & 42.3 & 62 \\
Radial line & Present & Present & Absent \\
\hline
\end{tabular}

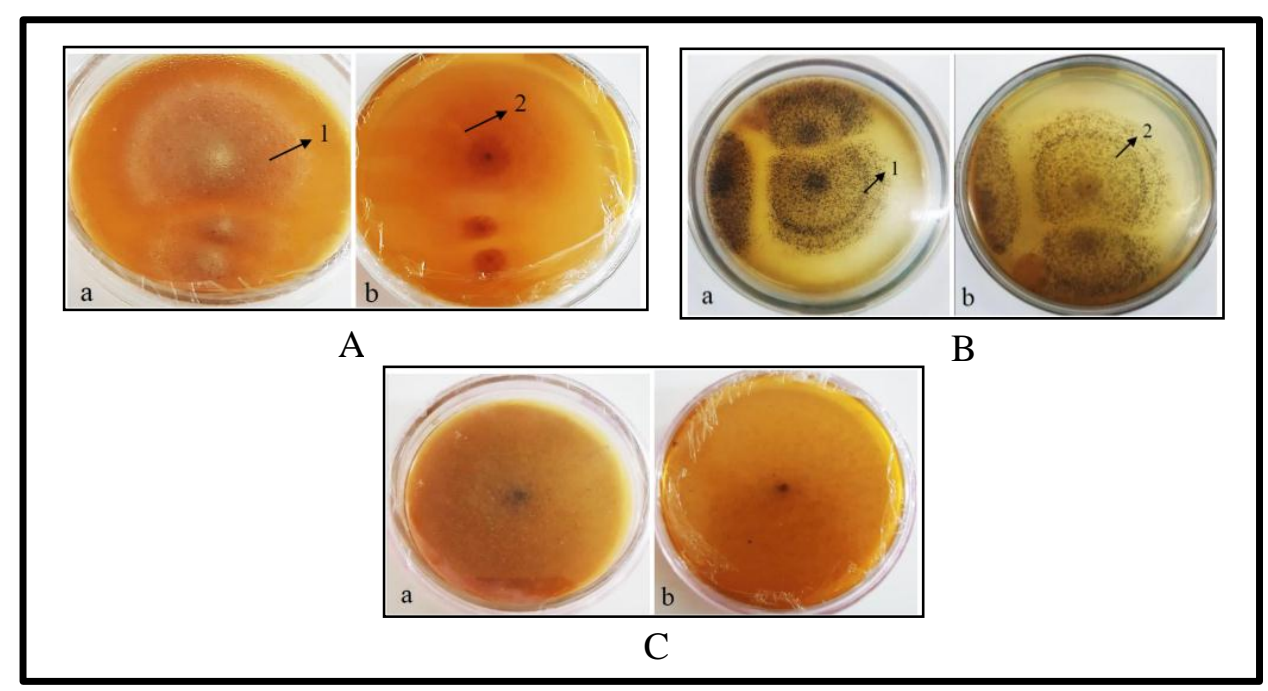

Figure 3. Colony morphology on media PDA at 7 days incubation. (A) isolate KC1 (B) isolate KE1 (C) isolate KE6, a: observe colony, b: reverse colony, 1: zonation, 2: radial line 
Table 4. Microscopic characteristics of PHB-degrading lipolytic mold

\begin{tabular}{lccc}
\hline \multirow{2}{*}{ Characteristics } & \multicolumn{3}{c}{ Isolate Code } \\
\cline { 2 - 4 } & KC1 & KE1 & KE6 \\
\hline Asexual spore & conidia & conidia & conidia \\
Foot cell & present & present & present \\
Hyphae type & septate & septate & septate \\
Vesicle type & Sub clavate & Globose & Broadly clavate \\
Conidia type & round & round & round \\
Conidia colour & hyaline & black & hyaline \\
Conidia margin & smooth & rough & smooth \\
Conidiophore colour & hyaline & hyaline & hyaline \\
Conidiophore surface & smooth & smooth & smooth \\
Conidiophore size & long & long & short \\
Type of spore in vesicle & rotate & rotate & rotate \\
Location of spore mass & phialide apex & phialide apex & phialide apex \\
Phialide & biseriate & biseriate & uniseriate \\
\hline
\end{tabular}

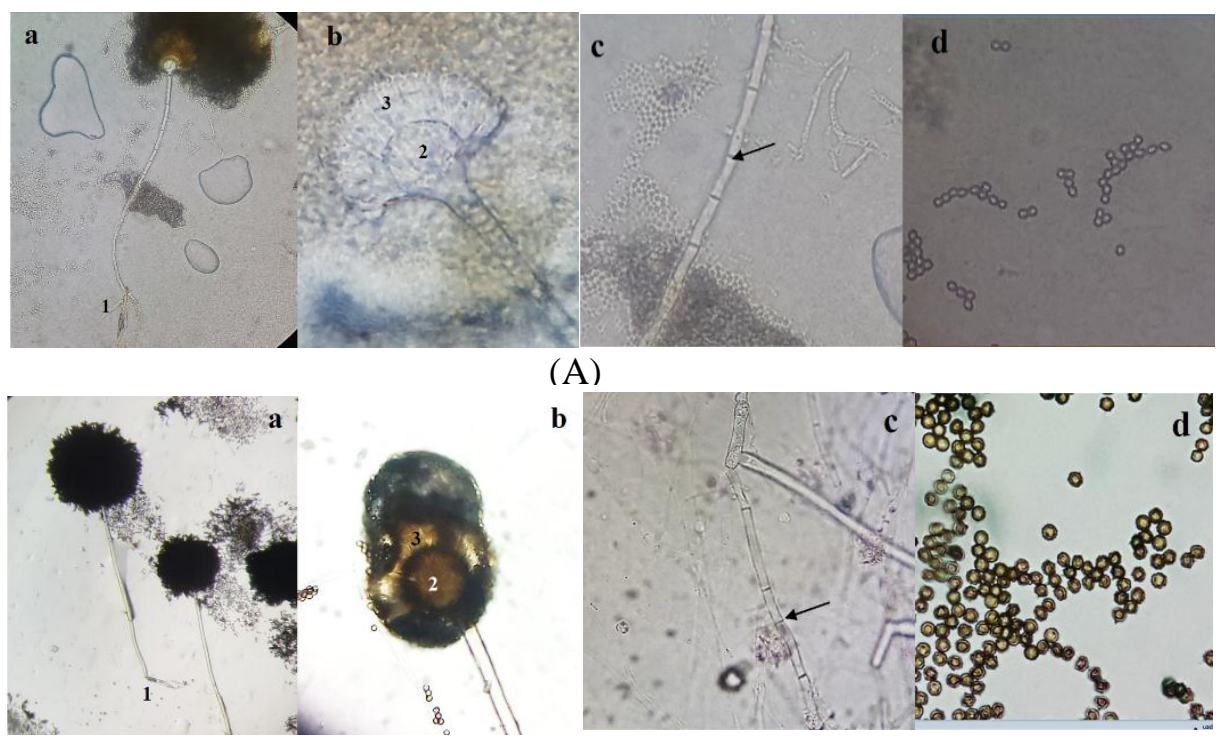

(B)

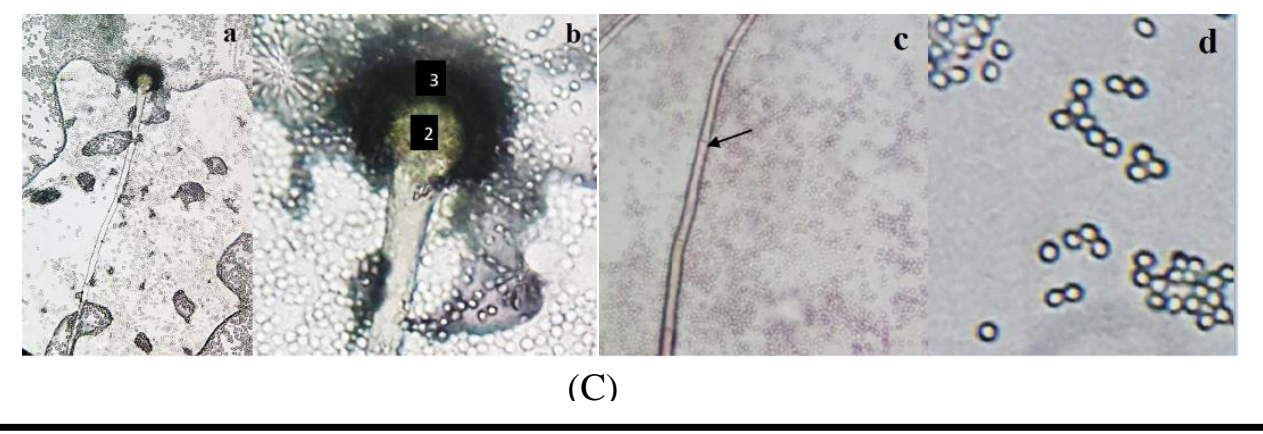

Figure 4. Light microscopic photographs (A) isolate $\mathrm{KC1}$ (B) isolate KE1 (C) isolate KE6, 400x magnification, a: conidiophore and spore mass, 1: foot cell b: morphological structure, 2: vesicle, 3: phialid, c: septate hyphae, d: conidia 
d. Identity of PHB-degrading lipolytic molds

The first identification was done to determine the genera of isolates according to the phenotipic characters compared to the certain key character in Illustrated Genera of Imperfect Fungi (Barnett and Hunter, 1987) and Training course for identification of Aspergillus, Penicillium and Talaromyces (Samson, 2017). The result showed that all PHB-degrading fungi isolates were a member of Aspergillus due to their indentical phenotipic characters to this genera (Table 5).

Table 5. Profile mathcing between key characters of Aspergillus to isolates

\begin{tabular}{lcccc}
\hline \multicolumn{1}{c}{ Characters } & Aspergillus & KC1 & KE1 & KE6 \\
\hline Asexual spore & Conidia & conidia & conidia & conidia \\
Footcell & Present & Present & Present & Present \\
Hyphae type & Septate & Septate & Septate & Septate \\
Conidiophore branch & Absent & Absent & Absent & Absent \\
Location of spore mass & phialide apex & phialide apex & phialide apex & phialide apex \\
\hline
\end{tabular}

Numeric-phenetic identification was done based on the similarity of 33 phenotipic characters between these 3 mold isolates and 4 reference species, namely Aspergillus niger, Aspergillus terreus, Aspergillus flavus and Aspergillus fumigatus. Four reference species were selected based on the character similarity to the obtained isolates. The analysis results was visualizied on dendrogram as shown in Figure 5. Four clusters were formed and all genera in the cluster had similarity value more than $70 \%$. Isolate $\mathrm{KC} 1$ and Aspergillus terreus were in cluster 1 with $100 \%$ similarity value. This was indicated that isolate $\mathrm{KC} 1$ was identic to Aspergillus terreus. Isolate KE1 and Aspergillus niger were in cluster 2 with $94.3 \%$ similarity value. This indicated that isolate KE1 was identic to Aspergillus niger, while isolate KE6 and Aspergillus fumigatus were in cluster 4 with 94.3\% similarity value. This was indicated that isolate KE6 was identic to Aspergillus fumigatus.

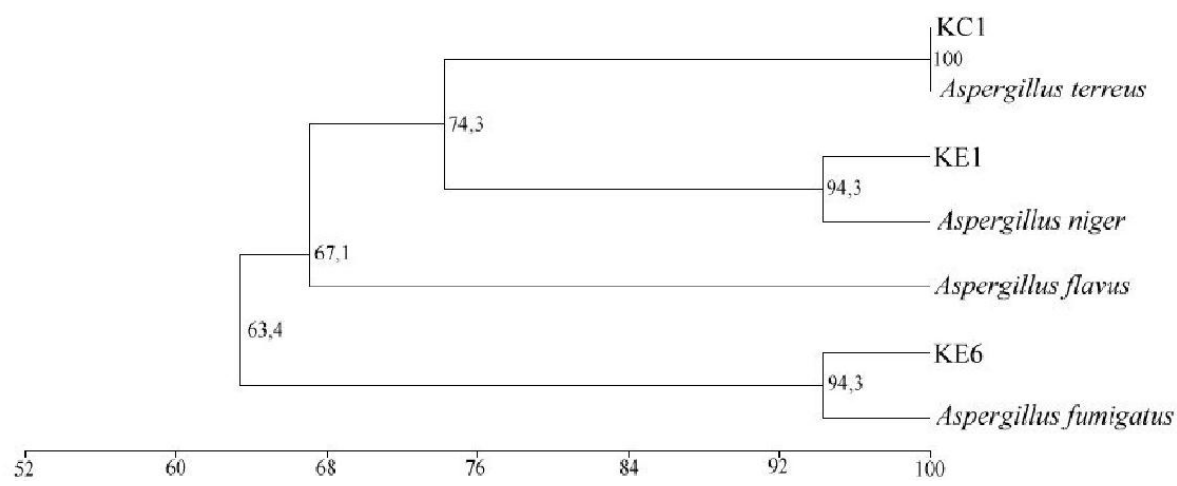

Figure 5. Dendrogram of similarity between 3 PHB-degrading lipolytic isolates and 4 reference spesies based on simple matching coeficient (SSM) and unweighted pair-group method with arithmetic average (UPGMA) using phenotipic characters. 


\section{Discussion}

Lipolytic molds can utilize lipid substrates as their carbon source by the action of lipase enzyme. They can be found at the appropriate environments, such as at industrial wastes, vegetable oil or milk factories, oil-contaminated soil, rotten food, compost and hot spring (Musa and Tayo, 2012; Sharma et al., 2001). In this study, isolate source was taken from Kendari landfill soil and there were 24 isolates had been obtained. The landfill soil is considered as a great source to obtain lipolytic molds due to many oil substrates or oil wastes are thrown there away. Some lipolytic screening methods have been proposed, one of them was rhodamine B agar method.

Rhodamine $\mathrm{B}$ is a fluorescence dye that will bind into the hydrolyzed fatty acid resulting the formation of orange fluorescent halos around the fungal colony (Kouker and Jaeger, 1987; Olusesan et al., 2009). In this medium, olive oil was used as lipid subsrate to stimulate the lipase activity. Orange fluorescent was formed due to the complexes binding between rhodamine B cation and uranil ion of the hydrolyzed fatty acid. According to the result, sixteen lipolytic mold isolates were found. Out of them, there were three lipolytic isolates with the highest lipolytic activity. Some studies have been also reported that this method was used to screen both fungal and bacterial lipolytic activities (Mendes et al., 2019; Ramnath et al., 2017). Furthermore, Kouker and Jaeger (1987) stated that this method was preferrable than others due to there was not inhibition effect to the growth or change in the physiological characters of microorganisms.

The ability of isolates to degrade biofilm PHB was observed based on the formation clear zone around the colony. The fungal growth and clear zone were checked everday. After 2 days, the clear zone was formed. This result was contrary with the study by Lee et al. (2005) who proposed that the clear zone observed after 1-3 weeks. As shown in Table 2, three lipolytic isolates were potential to degrade biofilm PHB. Jackson (1998) stated that the clear zone formation rate or PHB degradation rate was affected by four factors, such as growth rate, enzyme secretion, enzyme activity, and enzyme diffusion into agar medium. Suriawiria and Unus (1986) also stated that agar concentrations and growth conditions were affected the degradation rate of PHB. The degradation rate will be inhibited when agar concentration is exceeding $3 \%(\mathrm{w} / \mathrm{v})$ may likely due to the inhibition of enzyme diffusion into agar medium, while the growth condition affects fungal growth as well as degradation rate.

Enzyme which can catalyze the degradation of PHB is PHB depolymerase, but lipases also have been reported to catalyze this (Leja and Lewandowicz, 2010). Lipases catalyze the hydrolysis of ester bond at oil-water interface. Lipases can degrade PHB due to the present of ester bond in PHB monomer (Leja and Lewandowicz, 2010). Poirier et al. (1995) was proposed two process of PHB degradation, first is the attachment of enzyme into the particle surface and will form enyme-substrate complexes and the second is hydrolysis of PHB into soluble oligomer or monomer. [R]-3-hydroxybutirate acid is formed as the last product of this ennzymatic activity.

There are three lipolytic molds obtained from Kendari landfill soil which were potential to degrade $\mathrm{PHB}$, namely isolate $\mathrm{KC} 1, \mathrm{KE} 1$ and $\mathrm{KE6}$. Based on numeric-phenetic indentification, isolate $\mathrm{KC} 1$ is a member of Aspergillus terreus, isolate $\mathrm{KE} 1$ is a member of Aspergillus niger and isolate KE6 is a member of Aspergillus fumigatus. Aspergillus has been 
known as one of the most predominant genera of lipase-producing and PHB-degrading molds (Matavulj and Molitoris, 1992). Some studies also reported that these molds had the ability to degrade PHB (Kumaravel et al., 2010; Lodhi, et al., 2011; Merugu, 2012; Aburas, 2016; Aly et al., 2017).

\section{Conclusion}

Landfill soil can be a source of PHB-degrading lipolytic molds. Aspergillus terreus $\mathrm{KC1}$, Aspergillus niger KE1 and Aspergillus fumigatus KE6 are lipolytic molds which have the ability to degrade PHB biofilm. These lipolytic molds might be potential in degrading another bioplastics. Furthermore, their potential can be enhanced through optimization study so it might be applied at industrial scale.

\section{References}

Aburas, M.M.A., 2016. Degradation of poly (3-hydroxybutyrate) using Aspergillus oryzae obtained from uncultivated soil. Life science journal. 13(3): 51-56.

Aly, MM., Jaar, TAM. And Bukhari, FM. 2017. Poly- $\beta$-hydroxybutyrate degradation by Aspergillus fumigates isolated from soil samples collected from Jeddah, Saudi Arabia, Journal of Pharmacy and Biological Sciences 12 (1) : 53-61.

Barnett,H.L. and Hunter, B.B., 1987, Illustrated Genera of Imperfect Fungi, Fourth Edition, Macmillan Publishing Company, NewYork.

Bharti, S.N., and Swetha, G. 2016. Need for Bioplastics and Role of Biopolymer PHB: A Short Review. Journal of Petroleum and Enviromental Biotechnology. 7: 1-3.

Cappucino, J.G., and Sharman, N. 1987. Microbiology: A Laboratory Manual Second Edition. The Benjamin/Cummings Publishing Company. New York.

Falony, G., Armas, J.C., Mendoza, J.C.D., and Martínez Hernández, J.L. 2006. Production of extracellular lipase from Aspergillus niger by solid-state fermentation. Food Technol. Biotechnol. 44, 235-240.

Full, T., Jung, D., and Madigan, M. 2006. Production of Polyhydroxyalkanoates from soy mollasses oligosaccharides by new, rapidly growing Bacillus species. Lett. Appl. Microbiol. 43(4): 377-384.

Jackson, F.S., 1998, Bacteria from Extreme Environtment Degrades Polyhydroxyalkanoates, Thesis, Biotechnology Departement, UNSW.

Kouker, G and Jaeger, K.E. 1987. Specific and sensitive plate assay for bacterial lipases. Applied Environ. Microbiol. 53: 211-213.

Kumaravel, S., Hema, R., and Lakshmi, R., 2010. Production of Polyhydroxybutyrate (Bioplastic) and its biodegradation by Pseudomonas lemoignei and Aspergillus niger. E-journal of Chemistry. 7(S1): S536-S542.

Lafferty, R.M., Korstko, B., and Korsatko, W. 1988. Microbial Production of Poly (3hydroxybutyric acid). In. Rehm H.J. and Reed G. eds. Biotechnology. 6: 135-176.

Lee, K.M., Gimore, D.F., and Huss, M.J. 2005. Fungal Degradation of the Bioplastic PHB. Journal of Polymers and the environment. 13(3): 213-219.

Leja, K. and Lewandowicz, G. 2010. Polymer Biodegradation and Biodegradable Polimers, $J$. of Environ. Stud. 19(2). 255-266.

Lodhi, A.F., Hasan, F., Shah, Z., Hameed, A., Faisal, S., and Shah, A.A. 2011. Optimization of culture conditions for the production of poly (3-hydroxybutyrate) depolymerase from newly isolated Aspergillus fumigatus from soil. Pak. J. Bot. 43(2): 1361-1372. 
Matavulj, N. and Molitoris, H.P., 1992. Fungal degradation of polyhydroxyalkanoates and a semiquantitative assay for screening their degradation by terrestrial fungi. FEMS Microbiol. Rev. 103: 323-332.

Mendes, D.B., Silva, F.F.D., Guarda, P.M., Almeida, A.F., Oliveira, D.P., Morais, P.B and Guarda, E.A. 2019. Lipolytic Enzymes with hydrolytic and esterification activites produced by filamentous fungi isolated from decomposition leaves in an aquatic environment. Enzyme research. Volume 2019. Article ID 8182425. 1-13.

Merugu, R., 2012. Studies on PHB (polyhydroxybutyrate) degradation by some species of Aspergillus. International Journal of ChemTech Research. 4(3): 1111-1113.

Murray, A., 2010. Quality Control Method-99 Preparation and Use of Rhodamine B Lipase Agar. Alken-Murray Corporation. New Hyde Park.

Musa, H., and Tayo, B.C.A. 2012. Screening of Microorganisms Isolated from Different Environmental Samples for Extracellular Lipase Production. J. AU JT. 15(3): 181.

Nathania, T.R., dan Kuswytasari, N.D. 2013. Studi Potensi Isolat Kapang Wonorejo Surabaya dalam Mendegradasi Polimer Bioplastik Poli- $\beta$ - hidroksibutirat (PHB). J. Sains dan Seni Pomits. 2(2). E-56.

Olusesan, A.T., Azura, L.K., Abubakar, F., Hamid, N.S.A., Radu, S. and Saari, N. 2009. Phenotypic and molecular identification of a novel thermophilic Anoxybacillus species: A lipase-producing bacterium isolated from a Malaysian hotspring. World $J$. Microbiol. Biotechnol. 25: 1981-1988.

Panuthai, T., Sihanonth, P., Piapukiew, J., Sooksai, S., Sangvanich, P., and Karnchanatat, A. 2012. An extracellular lipase from the endophytic fungi Fusarium oxysporum isolated from the Thai medicinal plant, Croton oblongifolius Roxb. J. African Journal of Microbiology Research. 6(11): 2624.

Poirier, C., Nawrath, and Somerville. 1995. Production of Polyhydroxyalkanoats, A Family of Biodegradable, Plastics and Elastomers in Bacteria and Plants. J. Biotechnology. 13(2): 42-150.

Ramadas, N.V., Singh, S.K., Soccoi, C.R., and Pandey, A. 2009. Polyhydroxybutyrate production using agro-industrial residue as substrate by Bacillus sphaericus NCIM. 5149. 52(1).

Ramnath, L., Sithole, B., and Govinden, R. 2017. Identification of lipolytic enzymes isolated from bacteria indigenous to Eucalyptus wood species for application in the puping industry. Biotechnology Reports. 15:114-124.

Rathbone, S., Furrer, P., Lubben, J., Zinn, M. and Cartmell, S. 2009. Biocompatibility of polyhydroxyalkanoate as a potential material for ligament and tendon scaffold material. Journal of Biomedical Materials Research, 93A(4).

Samson, RA. 2017. Training course for identification of Aspergillus, Penicillium and Talaromyces. Westerdijk Fungal Biodiversity Institute, Utrecht The Netherlands

Sanjaya, Y., Nurhaeni, H., dan Halima, M. 2010. Isolasi, Identifikasi, dan Karakterisasi Jamur Entomopatogen dari Larva Spodoptera litura (Fabricius). J. Ilmu-ilmu Hayati dan Fisik. 12(3): 137. (in Indonesian)

Sharma, R., Chisti, Y., and Banerjee, U.C. 2001. Production, Purification, Characterization, and Application of Lipase. J. Biotechnology Advances. 19: 627-662.

Thakur, S. 2012. Lipases, its sources, Properties and Applications: A Review. Int. J. Sci. Eng. Res. 3(7): 1-29.

Yanti, N.A., Sembiring, L., Margino, S., and Muhiddin, N.H., 2013. A Study on Production of Poly- $\beta$-Hydroxybutyrate Bioplastic from Sago Starch by Indigenous Amylolytic Bacteria, J. Indonesian Journal of Biotecnology, 18(2), 144-150. 
Yanti, N.A., dan Muhiddin, N.H., 2016, Bioconversion of Sago Starch to Bioplastic Poly- $\beta$ Hydroxybutyrate (PHB) by Local Strain Bacterial Bacillus megaterium PSA10, J. Chem. Pharm. Res., 8(7), 918-923. 